\title{
The effectiveness of housing renovation programs in the Russian Federation
}

\author{
Pavel Kostrikin ${ }^{1, *}$ \\ ${ }^{1}$ Moscow State University of Civil Engineering, Yaroslavskoe shosse, 26, Moscow, 129337, Russia
}

\begin{abstract}
The Housing Stock Renovation Program in Moscow, endorsed in 2017, caused a large number of public and academic debates on its quality and potential efficiency as well as (in more general terms) on possible methods of estimating the effectiveness of government and municipal programs implementation in the Russian Federation. The relevance of these discussions is predicated, among other things, on huge funds actually injected by the Russian government (especially on the national and subnational levels) into various links of the national development and construction industry. More than 1.74 trillion rubles were allocated from the Moscow budget alone for the financing of various construction programs in 2018-2020. Inquiring into the existing and prospective methods of decision-making in the process of development, approval, execution and assessment of the housing stock renovation program efficiency as well as suggesting practical recommendations in the given sphere were the main goals of the research undertaken by the author. Using the comparative analysis of several earlier completed government programs versus similar ones or the recently adopted Moscow renovation program, their goals and objectives, the author identifies, pigeonholes and compares their basic parameters and targets which were or weren't actually attained. The undertaken research brings the author to the conclusion about the absence in the modern research, economic or practical circulation of any scientifically grounded methodology for ensuring a synchronous integrated real estate development and preset mechanisms of state participation in the investment and construction process, based, among other things, on bringing the target parameters of public (municipal programs) in conformity with their economic parameters.
\end{abstract}

\section{Introduction}

Launching the practical implementation of a rather large-scale program of rundown and failing housing renovation in Moscow, which in the initial four years alone, including the starting year 2017, requires 400 billion rubles, with 1.74 trillion rubles set aside in the Moscow budget of 2018-2020 for the financing of construction programs, gives rise to a legitimate concern about the economic efficiency of the planned outlay. This issue proves rather uneasy even in terms of its correct phrasing. For while a variety of indicators (see the author's work [2] as well as materials [3], [4], [5]) have been developed, based on the analysis of investor's (developer's) revenue which is its key target, the government 
understandably pursues different goals in the programs calling for financial investments in construction activities. And this is not the only problem, as we further show.

The scale and complexity of the housing stock renovation problem in the Russian Federation have long been rousing the interest of domestic economists. Nevertheless, most works are devoted to the analysis of various regional programs which have more or less successfully been implemented literally all over the country. Standing out among them is the research of Z.F. Ibragimova on this problem solution in the Republic of Bashkortostan [6], the works of V.V. Bulgakov and I.S. Potapova on the situation in the Tambov region [7], the work of I.A. Luzhnova (Samara region - [8]) as well as the work of N.A. Ponyavina and V.I, Zakharova (Voronezh region - [9]).

There are not so many works on the problems under review in overseas sources. In the author's opinion, this can be explained by the fact that the overwhelming majority of programs targeting the demolition or revamping of the obsolete housing stock in developed markets were realized at the end of the previous century, and so the given problem is less relevant there now. Yet the research of R.J. Kleinhans [10] who analyzes the potential benefits from housing programs in the context of a broader urban regeneration policy in the Netherlands is worth mentioning. An interesting approach to the problem, based on the experience of Detroit, USA, can be found in the article of D. Peredes and M. Skidmore who suggest the comparison of direct outlay by local authorities on the demolition of rundown houses and subsequent regeneration of the urban land under them with the potential revenues of respective budgets from the property tax [11].

The analysis of developing markets (India - M. Mahadeva [12], Kazakhstan - L.B. Kulumbetova [13], China - Xin Lia, Reinout Kleinhansa, Maarten van Hama [14], Lü Junhua [15]), while encouraging a look at the problem under review at ancommon angle in some cases, generally proves inapplicable to national economic realities.

Still fewer interesting and relevant materials, in author's opinion, are dedicated to studying the effectiveness of government programs, while those works which are published on this subject (the works of A.I, Volosov [16], [17]; S.A. Vladimirov [18], [19]; E.V. Pirogova [20]) place an emphasis on analyzing the government expenditures solely as investments, implying by virtue of their essence, direct or indirect economic gain for the government, which cannot be the main goal of state programs aimed at renovation of the antiquated housing stock.

\section{Materials and Methods}

We propose the development of relevant methods for assessing the effectiveness of new government programs for demolition (modernization) of failing, rundown or just morally outdated housing stock in the Russian Federation, based on comparative analysis of the goals, objectives and actual results of implementing several already completed (or in the process of completion) national and subnational programs having comparable parameters.

As the first example, let's consider the officially formulated objectives of the subprogram Resettlement of Russian Citizens from Failing and Rundown Housing that was part of the target national program "Dwelling" for 2002-2010. The following goals and objectives were stated for this subprogram:

- providing housing for citizens dwelling in houses recognized as unfit for permanent residence;

- demolition until 2010 inclusive of failing housing stock (recognized as such in 2000) that existed as of the time of the subprogram adoption;

- preparing conditions and developing a mechanism of citizens' resettlement from the housing unfit for dwelling; the owner (i.e. government) keeping its commitments of the housing stock restoration; 
- $\quad$ optimizing the development of lands covered with housing unfit for dwelling as of the moment of launching the subprogram.

One can see that a significant part of the listed goals and objectives are social, urban planning, infrastructural and suchlike. In view of this fact, developers of the above-stated and similar programs or subprograms (both on the national, subnational and municipal levels) originally include several numerical benchmarks as a reference point for more or less correct assessment of the efficiency of each particular program at least as a percentage of the declared parameters' fulfillment. Thus in the subprogram under review, called "Resettlement of Russian Citizens from Failing and Rundown Housing", one such parameter for the first stage, i.e. from 2002 to 2004 was solely the floor space of dilapidated housing to be demolished - 2,406 thou sq. m. Which were the results of the given subprogram implementation in terms of the stated parameter? As per the main outcome of the first stage of the subprogram under review, formulated in Resolution \#675 of the Russian Government, dated 17 September 2001, failing and rundown residential buildings were taken down in 2002-2004 with the total floor space of only 630.4 thou sq. m, or just $26 \%$ of the planned target.

The next example: one of the first large-scale municipal programs actually implemented in the territory of Russia was The Program of Failing Housing Demolition and Rejuvenation of Decrepit Residential Neighborhoods in the City of Kazan, adopted back in 1995 and officially completed in 2005 (for more detail about this program see the author's article [4]). In view of apparent similarity of many goals and mechanisms in the given program with comparable parameters of the program being currently launched in Moscow, it seems expedient to enlarge upon Kazan's experience.

The main document that designated the economic mechanism of the program implementation in the capital of Tatarstan was the decree of the then RT President Mintimer Shaymiev "On Measures for Improvement of the Housing Conditions for Citizens Dwelling in the Dilapidated Housing Stock and Rejuvenation of Decrepit Residential Neighborhoods", dated 23 October $1995^{5}$, according to which a special purpose tax was introduced (subsequently approved by the State Council of Tatarstan) for getting rid of dilapidated housing. That tax levied on the volume of realized products (works, services) relative to their cost was $0.3 \%$ starting on 1 November $1995 ; 0.6 \%$ starting on 1 January 1997 and $1.0 \%$ starting on 1 January 1998.

What's more, the republican interdepartmental commission providing social security for the population in finalizing the spending estimates for extra-budgetary funds would annually forward some money to the state extra-budgetary housing fund (SEBHF) of Tatarstan, to finance special purpose works of demolishing the failing housing. The extra sources for SEBHF were:

- $\quad$ target contribution of businesses to the demolition of failing housing;

- $\quad$ oil sale excise duty funds in the amount of 15,000 rubles per tonne;

- $\quad$ part of rent payments from the public housing fund;

- $\quad$ property tax of individuals (residential buildings and apartments);

- investments and loans, including from foreign investors, used for integrated urban regeneration of decrepit residential housing neighborhoods;

- funds raised from the sale of space in rundown residential buildings as well as land parcels under them;

- $\quad$ unfinished residential housing construction projects handed over to the fund.

The SEBH was tasked with urban regeneration of decrepit housing neighborhoods and the use of land thereunder with regard for integrated development and conservation of the historical-architectural image of Kazan. The RT cabinet and the city administration transferred land titles to investors who would renovate rundown housing. The RT extrabudgetary housing fund would buy living premises for the resettlement of citizens from 
dilapidated housing stock, including in accordance with the procedure specified in the special regulations "On the redemption by the government of privately owned housing and living premises from citizens in need of social protection" - Decree \#327, dated 29 May 1995. It also developed regulations on preferential lending to citizens residing in dilapidated residential buildings for acquisition or construction of housing, providing respective financing. The developers of residential schemes for the resettlement of citizens from rundown housing were exempt from so-called "deductions" of some living space, enjoined by the local legislation. The quality and pricing control functions in the course of the program implementation were laid on the State Committee of Tatarstan for Construction and Architecture and the State Committee for Consumer Rights Protection. The spending of funds from the State Extra-Budgetary Housing Fund of Tatarstan was overseen by the Audit Directorate of RT President.

The official results of the program were approved in Resolution \#39-23 by the Kazan Soviet of People's Deputies, dated 25 May 2005:

- The program is recognized as fully realized and complete;

- The resettlement targets are totally hit, with 33,372 families moving into modern residential units with all amenities;

- In the course of the program implementation 315 multistory residential houses were built, with the total floor space of 2,070,442 sq. m;

- Capital investments stood at the level of 13,331.60 million;

- The program resulted in higher tax proceeds used for the financing of municipal economy and wage payments to municipal workers (no figures are cited);

- For the first time in Kazan commissioned housing exceeded 500,000 sq. $\mathrm{m}$ in $1999 ; 600,000$ sq. $\mathrm{m}$ in 2001 and 800,000 sq. $\mathrm{m}$ in 2004, which was well above the average per capita volumes for Russia; the program resulted in entire neighborhoods built in the city as well as in changes of the cityscape.

It is important to note that the above-mentioned final document also indicates the targets which were not hit, specifically:

- The program stakeholders failed to provide the residents of newly developed neighborhoods with ample social infrastructure;

- The renovation of some centrally located neighborhoods was not complete; this territory was not totally landscaped and the issue of historical heritage conservation and recreation was not addressed;

- About 3,500 families dwelling in 980 rundown houses were not included in the program, since those buildings were recognized as unfit for living after the program had been finalized (as per par. 2 of Article 57 of the RF Housing Code ${ }^{8}$, the given categories of citizens were liable to being provided with living space based on social contracts in a fasttrack manner).

The third equally interesting example is the objectives and results of implementing the Moscow program (or rather several programs replacing one another) of demolition in the inner city of five-story panel houses dating from the first period of industrial house building. The latter of these programs preceding the newly adopted renovation program was launched by Resolution \#608 of the Moscow Government, dated 06 July 1999 "On the objectives of integrated regeneration of five-story development neighborhoods dating from the first period of industrial house building, until 2010." The Moscow authorities emphasized continuity in relation to a similar document issued in 1998, admitting that the goals and objectives set therein with the year 2000 being the deadline could not be reached. The new program contained the following targets to be hit by 2010 :

- Total volume of demolished housing: 6.0 million sq. m, including not less than 700,000 sq. m every year; 
- Construction of at least 1.0 million sq. $m$ of living space every year for the resettlement of citizens from five-story panel houses to be demolished;

- Refurbishment, starting in 2001 of the buildings not subject to demolition in the amount of at least 200,000 sq. $\mathrm{m}$ of living space every year.

In the course of this program implementation its volume was redefined: 1,722 houses with the total floor space of 6.4 million sq. $\mathrm{m}$ were finally included in the program, while the program itself was repeatedly prolonged and by now it has finally been extended to 2018, which means that its official completion will coincide with the active phase of implementing the readopted renovation program. This gives grounds for the assumption that by the stated deadline the percentage of its parameters' execution will finally reach 100. As of mid-September 2017, 1,675 houses with the total floor space of 6.1 million sq. $\mathrm{m}$ had been pulled down and in 2018 the demolition of the remaining 47 five-story houses must be completed.

It should be noted that despite the lack of any official data to this effect, the program under review favorably compared with its predecessors due to the integrated approach to renovation of five-storied neighborhoods (which is also reflected in its name and in the text of the resolution that kick-started this program). Schools, day care centers, outpatient clinics and other social, energy and transport infrastructure facilities were timely built in the renovated neighborhoods in sufficient volumes. The lack of correct and comparable data about the synchronization of integrated development of the territories included in the program with implementation of the program itself can be explained by the fact that the construction of all requisite infrastructure has been carried out by the city authorities via different channels pertaining to different municipal programs, such as "Education", "Healthcare", "Transport development", "Infrastructure and Energy Conservation", "Developing the Urban Environment", "Urban Development Policy", "Moscow Sports" and "Moscow Culture".

\section{Results and Discussion}

The results of the above-mentioned comparative analysis, as regards a default on or partial fulfillment of some final indicators in the three programs under review, are summarized in Table 1.

Table 1. Unachieved Parameters of Some State (Municipal) Programs.

\begin{tabular}{|l|l|}
\hline Program (subprogram) name & Key unachieved parameters \\
\hline $\begin{array}{l}\text { Resettlement of Russian citizens from the } \\
\text { failing and rundown housing stock in 2002- } \\
2010 \text { (first stage) }\end{array}$ & $\begin{array}{l}\text { The volume of the demolished failing and } \\
\text { rundown housing stock }-26 \% \text { of the planned } \\
\text { target }\end{array}$ \\
\hline $\begin{array}{l}\text { Demolition of dilapidated housing and } \\
\text { regeneration of rundown housing } \\
\text { neighborhoods in Kazan }\end{array}$ & $\begin{array}{l}\text { The lack of an integrated approach to the } \\
\text { development of new neighborhoods }\end{array}$ \\
\hline $\begin{array}{l}\text { Integrated regeneration of five-story } \\
\text { neighborhoods dating from the first period of } \\
\text { industrial house building till } 2010 \text { in Moscow }\end{array}$ & Exceeding the stated deadline by 1.8 times \\
\hline
\end{tabular}

As can be seen from the table above, the indicators in the right column reflect absolutely different parameters by their economic nature; thus any correct comparison or substantial assessment of the actually achieved results of execution of various government programs seems impossible at present (using the existing tool kit).

Under delivery in the Russian Federation nowadays are at least two biggest national projects whose key parameters are summarized by the author in Table 2. The conclusion is 
similar: the target indicators and formulated goals will disable correct economic analysis of the achieved (or unachieved) results upon the completion of these programs.

Table 2. Objectives and anticipated results of execution of the effective national projects.

\begin{tabular}{|c|c|c|c|}
\hline Project name & Main objectives & $\begin{array}{c}\text { Target } \\
\text { indicators }\end{array}$ & $\begin{array}{l}\text { Anticipated final results } \\
\text { (indicators) }\end{array}$ \\
\hline $\begin{array}{l}\text { The } \\
\text { prioritized } \\
\text { project } \\
\text { "Mortgage } \\
\text { and Rental } \\
\text { Housing" } \\
(2016-2020)\end{array}$ & $\begin{array}{l}\text { 1. Ensuring the high } \\
\text { pace of building the } \\
\text { quality, comfortable and } \\
\text { affordable housing. } \\
\text { 2. Increasing the } \\
\text { affordability of } \\
\text { mortgage loans for } \\
\text { citizens and the } \\
\text { reduction of financial } \\
\text { risks by forming a liquid } \\
\text { market of mortgage- } \\
\text { backed securities, } \\
\text { introducing e-mortgages } \\
\text { and other measures. } \\
\text { 3. The delivery of } \\
\text { special pilot rental } \\
\text { housing projects, } \\
\text { including through the } \\
\text { mechanism of mutual } \\
\text { investments and } \\
\text { developing proposals to } \\
\text { further the rental } \\
\text { housing market on this } \\
\text { basis. }\end{array}$ & $\begin{array}{l}\text { - commissioning } \\
\text { of } 88 \mathrm{~m} \text { sq. } \mathrm{m} \text { in } \\
2018 ; 100 \mathrm{~m} \text { sq. } \\
\mathrm{m} \text { in } 2020 ; \\
\text { - the issue of } \\
1 \mathrm{~m} \text { mortgage } \\
\text { loans in } 2018 \\
\text { and } 1.2 \mathrm{~m} \\
\text { mortgage loans } \\
\text { in } 2020 ; \\
\text { - attracting } 15 \mathrm{bn} \\
\text { rubles of } \\
\text { investments in } \\
\text { 2018 into rental } \\
\text { housing. }\end{array}$ & $\begin{array}{l}\text { - the AHML program for } \\
\text { involving more than } 13,500 \\
\text { hectares of federal lands in } \\
\text { housing construction in the } \\
\text { cities with population } \\
\text { exceeding } 250,000 \text { residents } \\
\text { has been implemented; } \\
\text { - total commissioned housing } \\
\text { exceeded } 21.2 \mathrm{~m} \text { sq. m; } \\
\text { - mortgage-backed securities } \\
\text { (MBS) under the surety of } \\
\text { AHML have been issued; by } \\
\text { late } 2020 \text { the share of MBS } \\
\text { under the surety of AHML will } \\
\text { account at least for } 40 \% \text { of the } \\
\text { total MBS issue; } \\
\text { - the mortgage market has } \\
\text { been converted to the } \\
\text { electronic format; } \\
\text { - pilot projects of rental } \\
\text { housing and apartments in the } \\
\text { biggest cities of Russia via the } \\
\text { mechanisms of mutual } \\
\text { investment funds have been } \\
\text { delivered; by the end of } 2020 \\
\text { such funds will have the total } \\
\text { of } 65 \text { bn rubles. }\end{array}$ \\
\hline $\begin{array}{l}\text { The } \\
\text { prioritized } \\
\text { project } \\
\text { "Forming a } \\
\text { Comfortable } \\
\text { Urban } \\
\text { Environment } \\
\text { in 2017- } \\
\text { 2020." }\end{array}$ & $\begin{array}{l}\text { 1. Improving the quality } \\
\text { of urban environment. } \\
\text { 2. New modern } \\
\text { landscaping rules are } \\
\text { embraced. } \\
\text { 3. Collecting best } \\
\text { practices of delivering } \\
\text { landscaping projects } \\
\text { from all regions. } \\
\text { 4. Launching the } \\
\text { national register of best } \\
\text { implemented } \\
\text { landscaping practices } \\
\text { (projects). } \\
\text { 5. Creating a system of } \\
\text { the urban environment } \\
\text { quality assessment. }\end{array}$ & $\begin{array}{l}\text { - the number of } \\
\text { landscaping } \\
\text { projects in the } \\
\text { territory of } \\
\text { Russia by 2020, } \\
\text { included in the } \\
\text { national register } \\
\text { of best } \\
\text { implemented } \\
\text { practices } \\
\text { (projects): } 400 .\end{array}$ & $\begin{array}{l}\text { - new modern landscaping } \\
\text { rules are embraced by } \\
\text { municipal entities in Russia } \\
\text { from } 2017 \text { to } 2020 \text {; } \\
\text { - measures to shape a } \\
\text { comfortable urban } \\
\text { environment, including the } \\
\text { landscaping of courtyards, are } \\
\text { taken in } 2017-2020 \text { in different } \\
\text { regions of Russia; } \\
\text { - the urban environment } \\
\text { quality assessment system has } \\
\text { been developed and } \\
\text { implemented. }\end{array}$ \\
\hline
\end{tabular}

In the author's opinion, the proposed integral indicator based on the construction cost of new housing handed over to new owners by nongovernment stakeholders of integrated development and/or urban regeneration projects could be one of the possible functionally 
applicable indicators, reflecting the success/failure of specific government programs. The proposed indicator (Integral Cost Indicator, ICI) takes into account the split of expenditures between the government (municipality) and private developers of a specific neighborhood as well as structures in the form of the investment support matrix suggested by the author in a number of works [21].

$$
I C I=\frac{\sum_{i=1}^{W} C_{3_{i}} \times M+\sum_{j=1}^{V} V_{t_{j}} \times W A C C_{t_{j}}}{\text { Sresidential units }} \rightarrow \min
$$

where:

$\mathrm{C}_{\mathfrak{\vartheta}_{\mathrm{i}}}$ - the cost of development elements (stages), rubles

M - the investment support matrix for integrated development of the model neighborhood under review,

$\mathrm{T}$ - the time of delivering a project of construction (renovation) of a model neighborhood (for $\ni_{1}-\ni_{N}$ elements and during 6 months after commissioning), months,

$\mathrm{V}_{\mathrm{tj}}$ - funds invested into a project by nongovernment developers - stakeholders of the development partnership - on the j-month, rubles,

$\mathrm{WACC}_{\mathrm{tj}}$ - weighted average capital cost for developers in the $\mathrm{j}$-month of the project delivery, shares,

S residential units - total (net) living space handed over to buyers, sq. m

\section{Conclusions}

Based on the results of the retrospective analysis given, the author thinks it absolutely necessary to develop a scientifically grounded methodology to ensure the synchronization of integrated real estate development with the program mechanisms of government involvement in the investment-construction process. In the author's opinion, the following recommendations for the developers of state (municipal) programs should be taken into consideration:

- a clear separation in the aggregate cost parameters of the sources into budgetary (participating in the follow-up analysis of the effect reached from public allocations) and extra-budgetary (their amount can be used as a target indicator in its own right);

- indication of the program goals and objectives to be financed from other sources (programs) for their correct accounting;

- $\quad$ in defining the goals and objectives of the newly developed government programs it is mandatory to also identify an exhaustive list of target indicators (parameters) for assessing the effectiveness of the program in general; addressing the given problem will require, among other things, the development of correct methods for estimating such indicators as the provision with social and transport services, sustainability, etc.;

- forming an integral indicator taking into account all differential target indicators preset in the program with the establishment of their weights depending on the priorities of a government (municipal) agency approving each particular program.

\section{References}

1. E. Zyabbarova, Moscow Budget for 2018 and Planned Period of 2019-2020 Confirms Successful Economic Development of the Capital City (The portal of the Moscow city Duma, 2017)

2. P.N. Kostrikin, Investment support of real estate development: Monograph (LAP LAMBERT Academic Publishing, Saarbrücken, 2016) 
3. S. Collier, Construction funding: the process of real estate development, appraisal, and finance (John Wiley and Sons, N.Y., 2007)

4. B. Richard, Professional Real Estate Development: The ULI Guide to the Business (ULI-the Urban Land Institute, Washington, D.C., 2003)

5. G. Sorger, Dinamic economic analysis (Cambridge University Press, 2015)

6. Z.F. Ibragimova, Education \& Economics 1, 69-73 (2015)

7. V.V. Bulgakov, I.S. Potapova, Modern Trends in Science in Technology 9-6, 24-27 (2016)

8. I.A. Luzhnova, Herald of Samara Municipal Administration Institute 4, 65-69 (2010)

9. N.A. Ponyavina, V.I. Zakharova, Modern Problems and Prospects of Real Estate Development and Facility Management, 197-202 (2016)

10. R.J. Kleinhans, Housing Policy and Regeneration (International Encyclopedia of Housing and Home, 2012)

11. D. Paredes, M. Skidmore, Regional Science and Urban Economics 66, 16-27 (2017)

12. M. Mahadeva, Habitat International 30-3, 412-433 (2006).

13. L.B. Kulumbetova, The Digest of International Research to Practice Conference. Modern Science: Problems and Ways of Their Solution, 259-263 (2015)

14. X. Lia, R. Kleinhansa, M. van Hama, Shantytown redevelopment projects: State-led redevelopment of declining neighbourhoods under market transition in Shenyang China (Cities, 2017)

15. L. Junhua, Cities 14-2, 59-69 (2017)

16. A.I. Volosov, Managing the Efficiency of State Investments on the Basis of PublicPrivate Partnership (GUAP, SPb, 2008)

17. E.V. Pirogova, Materials of the Second Interuniversity Research to Practice Conference, 204-207 (2014)

18. S.A. Vladimirov, Credit \& Finance 3, 23-30 (2006)

19. S.A. Vladimirov, Problems of Contemporary Economics 4, 270 (2007).

20. A.I. Volosov, Developing the State Investment Management Forms: Master's thesis: 08.00.05 (Moscow, 2004)

21. P.N. Kostrikin, MGSU Herald 13-3, 339-348 (2018) 